\title{
Top-down control by insect predators in an intermittent pond $-a$ field experiment
}

\author{
A. Katarina Magnusson* and D. Dudley Williams \\ Department of Biological Sciences, University of Toronto at Scarborough, 1265 Military Trail, Scarborough, \\ Ontario M1C 1A4, Canada
}

Received 6 February 2009; Accepted 28 June 2009

\begin{abstract}
The role of predation in the regulation of freshwater communities is predicted to decrease along a habitat-duration gradient, from permanent to episodic waters. We tested the role of invertebrate predation in shaping the community structure in a fishless temperate intermittent pond with a three month long hydroperiod by comparing the community structure in two large field enclosures $\left(4.2 \mathrm{~m}^{2}\right)$ with added predators to two enclosures without added predators. The added predators reflected the density and composition of top predators in the pond and comprised weekly additions of dytiscid larvae (for three weeks) followed by weekly additions of odonate nymphs (for five weeks). Compared with the enclosure controls, the predator addition enclosures had fewer dipterans and crustaceans, higher concentrations of benthic ciliates and other protozoans, higher chlorophyll $a$ and bacterial counts, and lower abundance of rotifers. Many treatment effects were temporally variable and this appeared to be linked to predator identity, predator size, and prey availability. Compared with the surrounding pondwater, the enclosed areas had lower abundance of molluscs, ostracods and cladocerans but higher abundance of cyclopoids and higher concentrations of phytoplankton and ciliates. Despite high productivity and seasonally variable predator and prey assemblages, which likely buffered against strong top-down control, we conclude that the top-predators regulate the dipterans and zooplankton in this intermittent pond and that the effects propagated down through the food web to lower trophic levels.
\end{abstract}

Key words: Intermittent pond / predation / invertebrates / trophic cascade / Odonata / Dytiscidae / food web

\section{Introduction}

The goal with this study is to test the role of top-down control by insect predators in an intermittent pond. Intermittent ponds in temperate latitudes fill up with snowmelt-water in the spring and dry out a few weeks or months later. These are often fishless and highly productive habitats, characterized by strong seasonal community development and increasing habitat complexity (Williams, 2006). If the hydroperiod is sufficiently long, this productive environment provides an excellent breeding-and feeding ground for predatory insects, such as odonate nymphs, coleopteran larvae, and hemipterans - highly active predators that consume any prey they can capture, including congenerics (Deding, 1988; Jeffries, 1988; Nilsson and Söderström, 1988; Johansson and Nilsson, 1992; Kehl and Dettner, 2003; Aditya and Saha, 2006;

\footnotetext{
*Corresponding author: a. katarina .magnusson@gmail.com
}

Rubbo et al., 2006). Insect predators may reach very high densities in the absence of fishes (e.g., > 1000 odonates per $\mathrm{m}^{2}$, review by Corbet (1999)), whereupon they may regulate, and in some cases eliminate, their prey (e.g., Sih et al., 1985; Batzer and Wissinger, 1996; Jeffries, 1996; Blaustein, 1998). Many intermittent pond inhabitants grow rapidly and complete their life cycle before the pond dries. To achieve this, they tend to spend more of their energy on an active lifestyle than on predator defence (e.g., review by Wellborn et al., 1996; Johansson and Suhling, 2004). Therefore, insect predators may play an important role in the regulation of intermittent pond communities.

The question of whether insect predators exert topdown control in intermittent ponds is, however, rather complex. Many littoral predators are generalist feeders (e.g., Koperski, 1998) and insect top predators are among the last arrivals to the ponds; therefore, high densities of large-bodied predators typically co-occur with high levels of resources (e.g., Wiggins et al., 1980; Schneider and 
Frost, 1996; Schneider, 1997) which provide them with many alternative prey types. In addition, communities in intermittent ponds undergo continuous shifts in composition, structure, and food and habitat requirements (Batzer and Wissinger, 1996; Wellborn et al., 1996; Williams, 2006) and only species with specialized traits (e.g., broad physicochemical tolerance, rapid growth and development, and the ability to escape pond drying) survive the large fluctuations in physicochemical variables and the disappearance of water (Williams, 2006). Moreover, the developing vegetation increases the availability and diversity of suitable microhabitats for both prey and predators (de Szalay and Resh, 2000; Bazzanti et al., 2003; Taniguchi and Tokeshi, 2004; Biggs et al., 2005; Hauser et al., 2006; Carchini et al., 2007) and may increase the availability of refuges from predators (Peckarsky, 1982; Burks et al., 2001). The high productivity and prey heterogeneity could, together with the rapid community development, limit the strength of top-down control in these systems. Interspecific interactions increase, however, as the pond dries and organisms are concentrated in the shrinking habitat.

Few studies have examined the effects of insect predators in natural wetlands. Thus, the invertebratezooplankton-meiofauna coupling in these systems is not well known (Batzer and Wissinger, 1996; Schmid-Araya and Schmid, 2000). Similarly in intermittent ponds, prey preference and habitat selection of predators, and their potential to cause top-down regulation and trophic cascades, are not clear. In the present study we examine whether insect predators affect the biota in a natural intermittent pond. Instead of conducting the experiment in several ponds along a hydroperiod-length gradient, we chose to focus on one pond but at a greater level of detail. This approach enabled us to quantify responses of several food web components through time and to identify potential trophic cascades.

Our main objective here is to test the role of insect predators in regulating the pond community structure by comparing the community composition in enclosures with added insect predators to enclosures without any added predators. We expected that: (1) addition of top-predators results in lower abundance of large invertebrates and zooplankton (e.g., crustaceans, mosquitoes, midges, and other late instar insects) due to increased rate of predation (cf., Johnson et al., 1987; Schneider, 1999); and that (2) these effects propagate down through the pond food web (cf., Blaustein et al., 1995; Stav et al., 2000; Wojdak, 2005) and affect abundances/concentrations of smaller organisms (e.g., early instar insects, nauplii, rotifers and ciliates; $c f$. ., Cooper (1983), Schneider (1999), Hampton and Gilbert (2001)). Such changes may in turn, be reflected in the concentrations of chlorophyll $a$ and bacteria because phytoplankton and bacteria are important food sources for many protozoans (cf., Berninger et al., 1991; Nakano et al., 1998; Hoekman, 2007). Our second objective is to evaluate the realism of the study by comparing the biota inside the enclosures with the surrounding pond water.

\section{Material and methods}

\section{Study site}

We conducted this study in Vandorf Pond - an intermittent pond located on the Oak Ridges Moraine in southern Ontario, Canada. The pond was visited once a week throughout the hydroperiod of 2001. The pond filled up with snowmelt water in early spring (early April) and dried out four months later (mid-July). Maximum surface area was $2000 \mathrm{~m}^{2}$ and maximum water depth $0.3 \mathrm{~m}$. The pond bed consists of a thick layer of organic material and holds a mix of submerged, floating, and emerged aquatic plants. Deciduous and conifer trees surround the pond. During the experiment, temperature in the pondwater was $2-18^{\circ} \mathrm{C}$ (min-max), dissolved oxygen $0.3-4.7 \mathrm{mg} . \mathrm{L}^{-1}, \mathrm{pH}$ 5.9-6.6, total phosphorus $0.7-6.4 \mathrm{mg} . \mathrm{L}^{-1}$, and nitrate $0.8-1.8 \mathrm{mg} . \mathrm{L}^{-1}$.

\section{Manipulations}

Top-down effects were tested by comparing the community composition in two field enclosures with added insect predators ('predator addition' or 'predation' enclosures) to two field enclosures without any added predators ('enclosure control' or 'control'). The four enclosures consisted of large galvanized-steel sheets formed into a circle $\left(2.4 \mathrm{~m}\right.$ in diameter, $4.2 \mathrm{~m}^{2}$; with the sheet ends joined and made water-tight) and driven $5 \mathrm{~cm}$ into the substrate. The enclosures corralled homogeneous sections of the ponds; they were open to the pond bottom but prevented free exchange of water and organisms between the enclosures and the surrounding natural pond. Thus, predators and prey could not colonize the enclosures from the surrounding pond area but could freely emerge from dormant/overwintering stages in the pond bed and colonize through air (which allowed, for example, odonates to lay their eggs).

There were few large predators present in the pond for the first four weeks after snow melt. This time period is referred to as the 'pre-manipulation' period. Larger predators started to appear five weeks after pond filling (May 1) and mainly consisted of immature dytiscids (Coleoptera: Dytiscidae) followed by odonates (Odonata: Libellulidae). From this time and onwards, large individuals were transferred on a weekly basis from the surrounding pond area to the two predator addition enclosures. The size, number, and species of the added predators shifted over time to mimic the natural assembly and density of top predators in the pond. Only the largest predators were selected for the additions to ensure that only top predators were used in the manipulations. Assuming that the predator density inside the enclosure was similar to outside the enclosures, the additions would result in a doubling of the natural density of toppredators. The purpose with the selected density was to achieve measurable effect size on the prey community 
without inflating the risk of cannibalism among the predators.

The predator manipulations comprised three weeks of beetle larvae additions (10 large beetle larvae per week and enclosure on May 1,8 and 15) followed by five weeks of dragonfly nymph additions (20 dragonfly nymphs per week and enclosure on May 22, 29, and June 5, 12, 19). The size of large dragonfly larvae increased for each week so the five weeks of dragonfly additions could be divided into two periods, one with smaller odonates (first two weeks) and one with larger odonates (last three weeks). In total, 30 large predatory beetle larvae (17 Agabus sp.; 3 Rhantus binotatus Harris; and 10 Acilius semisulcatus Aube) and 120 odonate nymphs (a mix of Sympetrum obtrusum Hagen, S. internum Montgomery, and S. costiferum Hagen) were added to each of the two predator addition enclosures (equal to 35.7 predators per square meter over the hydroperiod or 2.4 to 4.8 predators per square meter and week). No predators were added to the two enclosure controls.

Odonate nymphs and dytiscid larvae are visual predators - dytiscids are good swimmers and divers, but mostly prefer to feed close to the substrate (Tate and Hershey, 2003), whereas odonates sit and wait on the substrate and devour any passing prey (Pritchard, 1964, 1965; Smith and Pritchard, 1968; review by Batzer and Wissinger, 1996). Results from prior laboratory feeding experiments and gut content analyses of the dominant toppredators in Vandorf Pond are described in Febria et al. (2005) - from these experiments we knew that the dytiscid larvae and Sympetrum nymphs in Vandorf Pond feed on ostracods, cladocerans, chironomids, culicids, nematodes, oligochaetes, leeches, dytiscid larvae, odonates, mites, algae, detritus, fungi, and leaf- and plant material.

In addition to the four enclosures, two non-enclosed areas of similar shape and size as the enclosures (herein referred to as 'pondwater control' or surrounding pondwater) were established to measure any potential enclosure effects.

Treatment effects are referred in here to both predator effects (differences between the manipulated enclosures and the un-manipulated enclosures, predator addition/ enclosure control) and enclosure effects (differences between the un-manipulated enclosures and the nonenclosed areas of the pond, enclosure control/pondwater control).

\section{Sampling}

The natural densities and composition of predators were determined each week by running a large D-frame dip net $(250-\mu \mathrm{m}$ mesh, $0.35 \times 0.30 \mathrm{~m}$ opening) along longitudinal transects through the water column, covering an area roughly equal to two enclosures $\left(9 \mathrm{~m}^{2}\right)$. All predators were transferred to a tray for identification, and the largest and most abundant predator taxa were transferred to the predator addition enclosures, an equal number of individuals to each of the two enclosures.
Representatives of the added predators were sampled in addition and preserved in formalin and brought back to the laboratory to confirm identification. No predators were added to the enclosure controls.

The enclosures and surrounding pondwater was sampled once a week for waterchemistry, chlorophyll $a$, and benthic microfauna, and every $2-4$ weeks for meio- and macrofauna. Thus, samples were taken from the premanipulation period (April 4, 11, 18 and May 1, 'pre') and one week after each predator addition (May 8, 15 and 22 for coleopterans 'col', May 29 and June 5 for early odonates 'odo1', and June 12, 19 and 26 for late odonates 'odo2'). For meio- and macrofauna, the pre-manipulation comprised two sampling dates (April 4 and May 1), whereas the three predator phases each consisted of one sampling date ('col' on May 22; 'odol' on June 5; and 'odo2' on June 26).

Water temperature, dissolved oxygen, conductivity, and $\mathrm{pH}$ were measured in the pond with a portable Hydrolab (Hydrolab $\mathrm{H}_{2} \mathrm{O}$ multiprobe, Corporation, Austin, TX, USA). Pond water was obtained by pooling two replicate samples retrieved by lowering a sampling tube $(0.1 \mathrm{~m}$ diameter $)$ vertically through the water column, sealing the lower end, and pouring its content into a bucket. The water in the bucket was well stirred. For water chemistry analyses (total phosphorus, ammonia, nitrate, and turbidity), $250 \mathrm{~mL}$ were transferred from the bucket to a tight-sealed bottle and stored in a dark cooler until analyzed in the lab using a Hach Kit spectrophotometer (DR2000; Hach Company, Loveland, CO, USA). For bacteria enumeration, $20 \mathrm{~mL}$ were transferred from the bucket to a small container and preserved with glutaraldehyde ( $1 \%$ final concentration) and stored in the laboratory until further analyses when three replicate $0.5-1 \mathrm{~mL}$ samples were stained with acridine orange and filtered through a black nucleopore filter (Track. Etch membrane, Whatman $0.2 \mu \mathrm{m})$, and counted under an epifluorescence microscope.

Phytoplankton biomass was determined by filtering $250 \mathrm{~mL}$ of pond water within four hours of collection through a $1.2 \mu \mathrm{m} \mathrm{GF} / \mathrm{C}$ filter and extracting the chlorophyll $a$ in acetone (corrected for pheophytin, APHA (1995)). Periphyton, retrieved from $5.5 \times 2.5 \mathrm{~cm}$ glass slides that had been submerged in the pond for two weeks, was also extracted for chlorophyll $a$ in acetone. The benthic microfauna was sampled by submerging a closed $250 \mathrm{~mL}$ container and opening the lid close to the substrate at two random places in each sample location. In the laboratory, all microfauna was identified and enumerated under an inverted microscope (procedure described in detail in Andrushchyshyn et al. (2003)).

The meio- and macrofauna was sampled with a $0.033 \mathrm{~m}^{2}$ circular box sampler - all water inside the box sampler, except for the lower $5 \mathrm{~cm}$, was carefully retrieved and poured into a $52 \mu \mathrm{m}$ handheld net, and the filtered contents were preserved in $4 \%$ formalin (herein referred to as 'plankton sample'). The remaining water in the box sampler, together with the top $2 \mathrm{~cm}$ of the sediment, was similarly retrieved and preserved separately from 
the plankton sample ('benthic sample'). The plankton samples did not necessarily represent true planktonic taxa since vegetation was often present in the water column.

Each meio- and macrofauna sample was separated into two size fractions by rinsing the sample through a set of two sieves (i.e., $1 \mathrm{~mm}$ sieve secured on top of a $0.47 \mathrm{~mm}$ sieve). The large size fraction $(>1 \mathrm{~mm})$ was sorted for organisms under a magnifying lamp $(4 \times)$. Three subsamples were retrieved from each sorted and well-stirred sample with a pair of forceps $(3 \times 1 \%$ of the weight $)$. Three subsamples were also retrieved from each small size fraction $(0.47-1 \mathrm{~mm})$ by randomly withdrawing three $1 \mathrm{~mL}$ samples with a pipette $(3 \times 1 \%$ of the volume). The three subsamples were then pooled and sorted under a dissecting microscope $(\times 12)$. The organisms retrieved from the large-sized fraction were wet-weighed on an E. Mettler scale $(0.00005 \mathrm{~g}$ resolution, Type H6) after excess water had been removed with absorption pads. The wet weight measures were used to test for treatment effects within each taxonomic group.

It should be noted that since the manipulated toppredators did not appear in the pond until the time of the predator addition there was no opportunity to measure the density of large predators in the enclosures prior to the manipulations (they were not sufficiently abundant in the pre-manipulation period). In addition, the size of the box-sampler $\left(0.033 \mathrm{~m}^{-2}\right)$ was insufficient for accurately measuring the density of the manipulated predators in the enclosures (given the density in the surrounding pond water each sample would contain less than one individual). We cannot rule out the possibility that some of the added predators were lost due to cannibalism or predation. To ensure that the predator additions resulted in elevated densities of predators compared with the enclosure controls, predators were added on a weekly basis and the survival of predators were confirmed through qualitative observational studies of the water bodies. We assume that the density of the added predators did not increase progressively each week because the life history of the predators and observations of the community in the surrounding pond area suggested that many predators from the earlier additions had entered their adult stage and thereby lost their role as top-predators at the time of the later predator additions (large beetle larvae were rare in the pond at the time of the odonate additions).

\section{Data analysis}

The data in this report were analysed in a series of Multivariate Analysis of Variance (MANOVA) with abundance/concentration of related organisms as dependent variables and treatment (with three levels: predator addition ' $\mathrm{p}+$ ', enclosure control ' $\mathrm{c}$ ', and pondwater control 'o') and time (with four dates which also corresponds to predator type or manipulation-periods: premanipulation 'pre', beetle addition 'col', early odonate addition 'odo1', and late odonate addition 'odo2') as independent factors. Thus, predator effects and enclosure effects were tested in the same MANOVA. Only related taxa (similar regarding sampling method, taxonomic resolution, size-group or habitat-group) were included in the same MANOVA, giving a total of ten MANOVAs (including water chemistry and basal resources) each including two to seven dependent variables (listed in Table 1). Specific treatment effects, including predator effects (predator addition/enclosure control) and enclosure effects (enclosure control/pondwater control), were tested using planned contrasts of means for significant main or interaction effects. Significant interaction effects were further tested with planned contrasts for each time/ manipulation period separately (including tests for specific predator type: col, odo1, and odo2) whereas significant main effect were tested with all dates pooled (denoted 'all').

We used MANOVAs for all data analyses because several taxa were measured simultaneously and we regarded each time period as independent from previous time period (sampling occurred through removal; the community structure in intermittent ponds are characterized by rapid changes; many response organisms had short generation times; and relatively long time elapsed between the samples). Due to high variability between replicate samples, both over time and in each manipulation, the critical alpha value for rejecting each main effect was set, a priori, to 0.1 (all dates combined). Each planned contrast was Bonferroni corrected to account for the number of taxa tested in each MANOVA (critical alpha ranging from 0.014 to 0.05$)$. Data were $\log (x+1)$-transformed prior to the statistical analyses to obtain homogeneity of variance among tested groups. The effect size of each treatment is contrasted to the enclosure controls.

\section{Results}

\section{Naturally occurring predators and prey}

The first large-bodied top-predators to appear early in the hydroperiod were the dytiscid larvae Agabus in early May, followed by Acilius and Rhantus in mid-May (Fig. 1). These were replaced in late May by Sympetrum species (viz., S. internum, S. obtrusum, and S. costiferum), which dominated the top-predator community until the pond dried in mid-July (Fig. 1). Salamanders or newts were not observed in the pond.

The most abundant prey in the pond included oligochaetes (mean density ranging from $8000-68800 \mathrm{~m}^{-2}$ over the hydroperiod), copepods $\left(62600-188300 \mathrm{~m}^{-2}\right)$, ostracods $\left(7700-113900 \mathrm{~m}^{-2}\right)$, chironomids $\left(5200-16800 \mathrm{~m}^{-2}\right)$, and bivalves (4100-19600 $\mathrm{m}^{-2}$ ), and the smaller rotifers

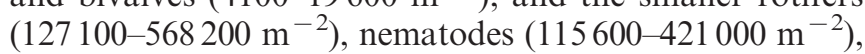
tardigrades (0-101500), and copepod nauplii (6400$91500 \mathrm{~m}^{-2}$ ). Trichopterans (Limnephilus sp.), with their large cases, were also common $\left(0-212 \mathrm{~m}^{-2}\right)$ but were not observed to be used as prey by the manipulated predators, neither in the field (this study), nor in previous laboratory studies (Febria et al., 2005). Dipterans peaked 
Table 1. Results from all MANOVA's that test for treatment effects (predator and enclosure effects) and time (date/manipulation) on the abundance, biomass or concentration of related dependent variables. Statistically significant $P$-values are denoted in bold $(P<0.1)$. Results from planned contrasts of specific predator effects are illustrated in Figures $2-9$.

\begin{tabular}{|c|c|c|c|c|c|}
\hline MANOVA/Effect & Value & $\mathrm{F}$ & Effect df & Error $\mathrm{df}$ & $P$ \\
\hline \multicolumn{6}{|c|}{ Abundance of major taxonomical groups (Insecta, Annelida, Mollusca; Fig. 2) } \\
\hline Time & 0.09 & 4.25 & 12 & 34.69 & 0.0004 \\
\hline Treatment & 0.24 & 4.55 & 6 & 26.00 & 0.0028 \\
\hline Treatment $*$ Time & 0.13 & 1.62 & 24 & 38.31 & 0.0881 \\
\hline
\end{tabular}

Biomass of major taxonomical groups (Insecta, Annelida, Mollusca; Fig. 3)

$\begin{array}{llllll}\text { Time } & 0.13 & 4.09 & 6 & 14 & \mathbf{0 . 0 1 4 1} \\ \text { Treatment } & 0.25 & 2.34 & 6 & 14 & \mathbf{0 . 0 8 9 0} \\ \text { Treatment*Time } & 0.51 & 0.45 & 12 & 18.81 & 0.9180\end{array}$

Abundance of dipterans (Chironomidae and non-chironomid dipterans; Fig. 4)

$\begin{array}{llllll}\text { Time } & 0.12 & 6.75 & 8 & 28 & \mathbf{0 . 0 0 0 1} \\ \text { Treatment } & 0.73 & 1.20 & 4 & 28 & 0.3337 \\ \text { Treatment*Time } & 0.17 & 2.54 & 16 & 28 & \mathbf{0 . 0 1 5 0}\end{array}$

Abundance of dipterans ( $\mathrm{b}>1 \mathrm{~mm}, \mathrm{p}>1 \mathrm{~mm}$, and $<1 \mathrm{~mm}$ Chironomidae and non-chironomid dipterans; Fig. 5)

$\begin{array}{llllll}\text { Time } & 0.01 & 3.67 & 24 & 36.10 & \mathbf{0 . 0 0 0 2} \\ \text { Treatment } & 0.28 & 1.49 & 12 & 20.00 & 0.2093 \\ \text { Treatment*Time } & 0.02 & 1.50 & 48 & 53.27 & \mathbf{0 . 0 7 6 8}\end{array}$

Abundance of crustaceans (Ostracoda, Cladocera, Cyclopoida, and Harpacticoida; Fig. 6)

\begin{tabular}{|c|c|c|c|c|c|}
\hline Time & 0.04 & 4.23 & 16 & 37.30 & 0.0001 \\
\hline Treatment & 0.04 & 12.53 & 8 & 24.00 & $<0.0001$ \\
\hline Treatment*Time & 0.09 & 1.32 & 32 & 45.85 & 0.1929 \\
\hline
\end{tabular}

Abundance of crustaeans ( $\mathrm{p}>1 \mathrm{~mm}, \mathrm{~b}>1 \mathrm{~mm}$, and $>1 \mathrm{~mm}$ total crustaeans; Fig. 6)

$\begin{array}{lccccc}\text { Time } & 0.07 & 5.16 & 12 & 34.69 & \mathbf{0 . 0 0 0 1} \\ \text { Treatment } & 0.17 & 6.24 & 6 & 26.00 & \mathbf{0 . 0 0 0 4} \\ \text { Treatment*Time } & 0.18 & 1.28 & 24 & 38.31 & 0.2406\end{array}$

Abundance of meiofauna (Acarina, Nematoda, Platyhelminthes, Tardigrada, Crustacea, Nauplius and Rotifera; Fig. 7)

$\begin{array}{llllll}\text { Time } & 0.02 & 2.26 & 28 & 33.87 & 0.0121 \\ \text { Treatment } & 0.14 & 2.18 & 14 & 18.00 & \mathbf{0 . 0 6 0 5} \\ \text { Treatment*Time } & 0.02 & 1.11 & 56 & 53.78 & 0.3460\end{array}$

Semi-quantitative abundance of benthic microfaunal taxa (Nematoda, Platyhelminthes, Tardigrada, Gastrotricha, Crustacea,

Protozoa and Rotifera; Fig. 7)

$\begin{array}{llllll}\text { Time } & 0.01 & 4.95 & 18 & 20.28 & \mathbf{0 . 0 0 0 4} \\ \text { Treatment } & 0.02 & 7.10 & 12 & 14 & \mathbf{0 . 0 0 0 5} \\ \text { Treatment*Time } & 0.02 & 1.26 & 36 & 33.50 & 0.2548\end{array}$

Abundance of resources (Ciliates, Bacteria, phytoplankton Chl $a$, periphyton Chl $a$; Fig. 8)

\begin{tabular}{|c|c|c|c|c|c|}
\hline Time & 0.10 & 2.84 & 12 & 24.10 & 0.0141 \\
\hline Treatment & 0.01 & 16.23 & 8 & 18 & $<0.0001$ \\
\hline Treatment $*$ Time & 0.02 & 2.71 & 24 & 32.61 & 0.0043 \\
\hline
\end{tabular}

Waterchemistry (Concentrations of turbidity, total P, and DO; Fig. 9)

\begin{tabular}{llrrrr} 
Time & 0.01 & 17.38 & 12 & 34.69 & $<$ \\
Treatment & 0.23 & 4.73 & 6 & 26 & $\mathbf{0 . 0 0 0 1}$ \\
Treatment*Time & 0.06 & 2.60 & 24 & 38.31 & $\mathbf{0 . 0 0 4 1}$ \\
\hline
\end{tabular}

in abundance early and late in the hydroperiod. Cladocerans increased with time while copepods and ostracods decreased log-linearly as the hydroperiod progressed, but larger-sized ostracods and copepods $(>1 \mathrm{~mm})$ peaked in mid-hydroperiod. Zooplankton were always more abundant than dipterans in the pond.

\section{Predator treatment}

\section{Total abundance and biomass}

The addition of predators resulted in a lower abundance of total insects $\left(-72 \%_{\text {odo } 2}\right.$ compared with 

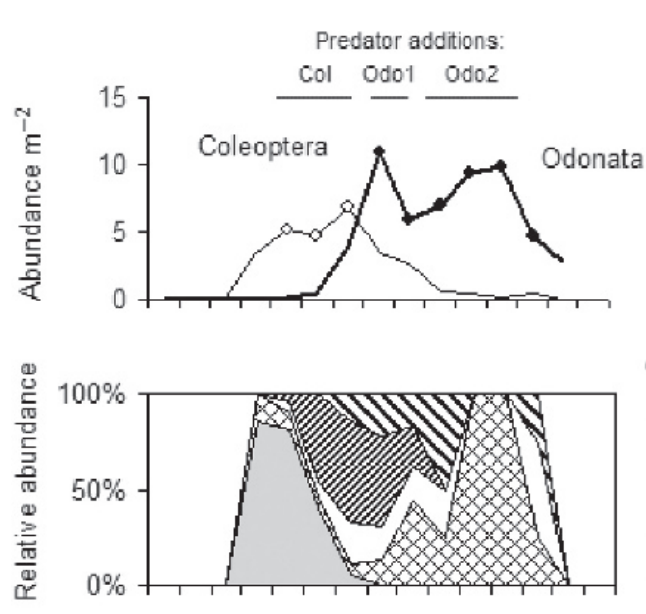

Coleoptera

$\mathbf{\Delta H y d a t i c u s}$

Acilius

$\square$ Dytiscus

囚Rhantus

$\square$ Agabus

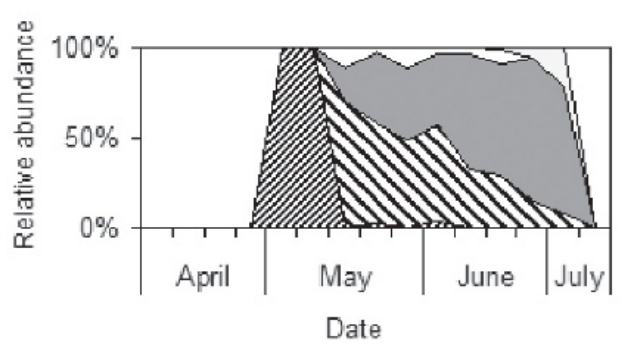

Odonata

$\square$ Anax spp.

$\square$ Aeshna spp.

$\square$ S. costiferum

$\mathbf{\Delta S}$. internum

S. obtrusum

Fig. 1. Seasonal development of large insect predators (Coleoptera and Odonata) in Vandorf Pond followed by the relative abundance of dominant taxa within each group. Circles and horizontal lines denote the time of the addition of coleopterans (open circles) and odonates (filled circles) to the predator addition enclosures.

the enclosure control, the subscript refers to the time period in which the effect was detected, $P<0.033$, planned contrasts following significant treatment effects in MANOVA, Table 1 and Fig. 2) and lower abundance of molluscs ( $-86 \%_{\text {odo2 }}, P<0.033$, Fig. 2$)$. This treatment did not, however, affect the abundance of annelids (n.s., Fig. 2) or the biomass of insects, molluscs or annelids (n.s., Fig. 3). The treatment effect on insects appeared to be chiefly due to predation by large odonates on chironomids (Fig. 4).

\section{Dipterans}

The addition of coleopterans also appeared to affect the abundance of dipterans because the abundance of large benthic chironomids (Chironomidae $\mathrm{b}>1 \mathrm{~mm}$ ) was $62 \%$ lower and the abundance of large benthic nonchironomid dipterans (non-chironomid dipterans $\mathrm{b}>1 \mathrm{~mm}$ ) was $79 \%$ lower in this manipulation compared with the enclosure control, but none of these effects were statistically significant (n.s., planned contrasts following significant treatment effects in MANOVA, Table 1 and Fig. 5). In contrast, the abundance of small non-chironomid dipterans (non-chironomid dipterans $<1 \mathrm{~mm}$ ) was significantly higher in the predator addition $(+340 \%$ col $)$ in comparison to the enclosure control $(P<0.017$, Fig. 5). The odonates did not appear to be size-specific regarding the chironomids since both size-classes of chironomids were negatively affected by this predator addition (Chironomidae $\mathrm{p}>1 \mathrm{~mm}$ : $-94 \%_{\text {odo } 2}$; Chironomidae b $>1 \mathrm{~mm}:-72 \%_{\text {odo } 2}$; Chironomidae $<1 \mathrm{~mm}:-89 \%_{\text {odo } 2}$, compared with the enclosure control, $P<0.017$, Fig. 5). Large non-chironomid dipteran larvae $(\mathrm{p}>1 \mathrm{~mm}$ and $\mathrm{b}>1 \mathrm{~mm}$ ) were not significantly affected by any of the predators (n.s., Fig. 5).

\section{Zooplankton}

The addition of predators was accompanied by lower abundance of crustaceans compared with the enclosure control (cyclopoids: $-47 \%$ all,$P<0.025$; large benthic crustaceans $\mathrm{b}>1 \mathrm{~mm}:-49 \%$ all,$P<0.033$; and small crustaceans $\mathrm{p}+\mathrm{b}<1 \mathrm{~mm}:-37 \%$ all,$\quad P<0.033$; planned contrasts following significant treatment effects in MANOVA, Table 1, Fig. 6). Treatment effects were only significant for all manipulations pooled and both the coleopterans and odonates tended to reduce both large and small crustaceans. The effects in ostracods $(-50 \%$ all $)$, cladocerans $\quad\left(-82 \%_{\text {odo } 1} ; \quad-39 \%_{\text {all }}\right), \quad$ harpacticoids $\left(-68 \%_{\text {col }} ;-20 \% \%_{\text {all }}\right)$, and large planktonic crustaceans $\left(\mathrm{p}>1 \mathrm{~mm}:-98 \%_{\mathrm{col}} ;-53 \%_{\text {all }}\right)$ were not statistically significant (n.s., Fig. 6).

\section{Lower trophic levels}

The addition of predators also resulted in lower abundance of crustaceans $(-39 \%$ all, $P<0.014)$ and rotifers $(-50 \%$ all,$P<0.014)$ in the meiofauna samples, and lower abundance of crustaceans $(P<0.025)$ in the benthic microfauna samples compared with the enclosure control, and in higher abundance of benthic protozoans (flagellates and amoebae, $P<0.025$, Table 1, Fig. 7). Moreover, ciliate abundance $(+2300 \%$ col,$\quad P<0.025$, Fig. 8), phytoplankton biomass $\left(+145 \%_{\mathrm{col}}, P<0.025\right)$, and bacterial abundance $\left(+62 \%_{\mathrm{col}}\right.$, n.s. and $+68 \%_{\text {odo } 2}$, $P<0.025)$ were higher in the predator addition enclosures compared with the enclosure control. Periphyton biomass was not significantly affected by the predator treatment $(-50 \%$ odo1 +2 , n.s., Fig. 8$)$. The predator addition also resulted in lower turbidity (20 FTU or $-21 \%_{\text {odo } 2}$, $P<0.033$, planned contrasts) and higher concentration of dissolved oxygen $\left(0.8 \mathrm{mg} . \mathrm{L}^{-1}\right.$ or $+100 \%$ odo2,$P<0.033$, Fig. 9). The treatments did not affect the concentration of total phosphorus ( $-35 \%_{\text {odo2 }}$, n.s., Fig. 9).

\section{Enclosure effect treatment}

\section{Total abundance and biomass}

The enclosed areas (enclosure control) had, averaged over all dates, similar densities of total insects (21 $600 \pm$ $6700 \mathrm{~m}^{-2}$, average \pm SE, n.s.) and annelids (42500 \pm $11700 \mathrm{~m}^{-2}$, n.s.), but lower abundance of molluscs $\left(3900 \pm 1600 \mathrm{~m}^{-2}, P<0.033\right.$ planned contrast following significant ANOVA, Table 1), compared with the surrounding pondwater (pondwater control: $16100 \pm 1000 \mathrm{~m}^{-2}$ 

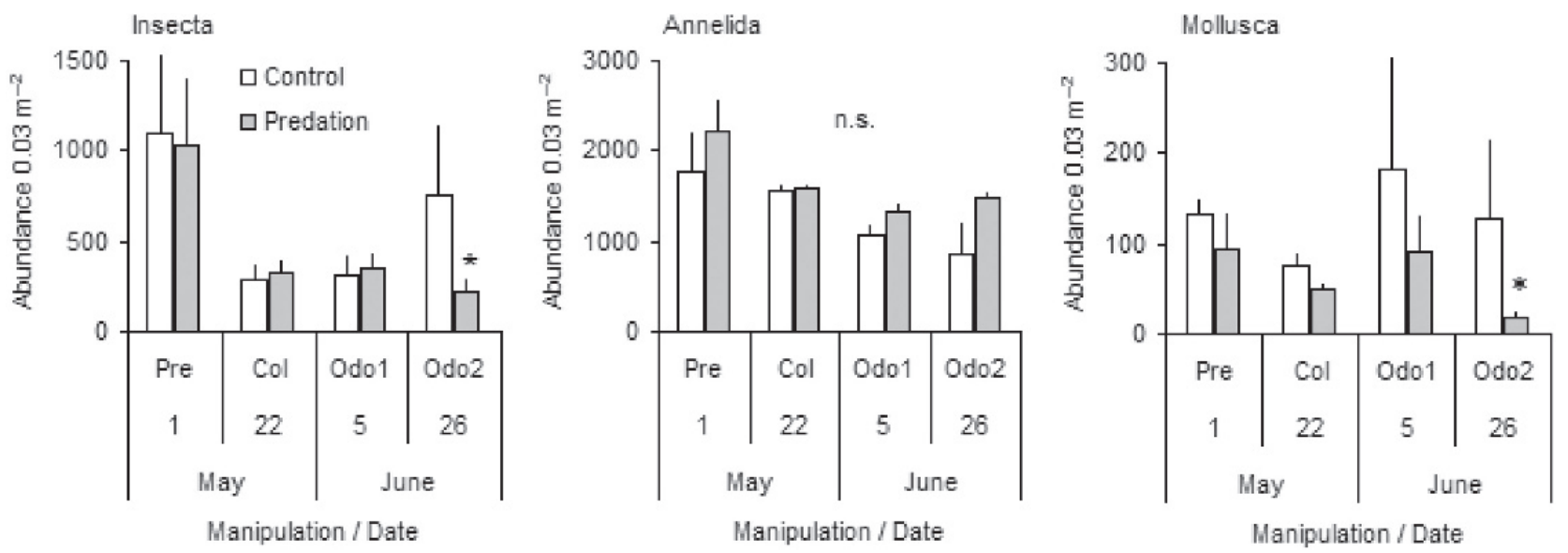

Fig. 2. Total abundance of insects, annelids, and molluscs in the predator addition enclosures and enclosure controls during each manipulation in Vandorf Pond (average \pm 1 SE per $0.03 \mathrm{~m}^{2}$ box sampler, $n=2$ ). Statistically significant differences between the treatment and enclosure control are denoted with an asterisk (Bonferroni corrected $P<0.033$ ) and non-significant effects are denoted n.s.

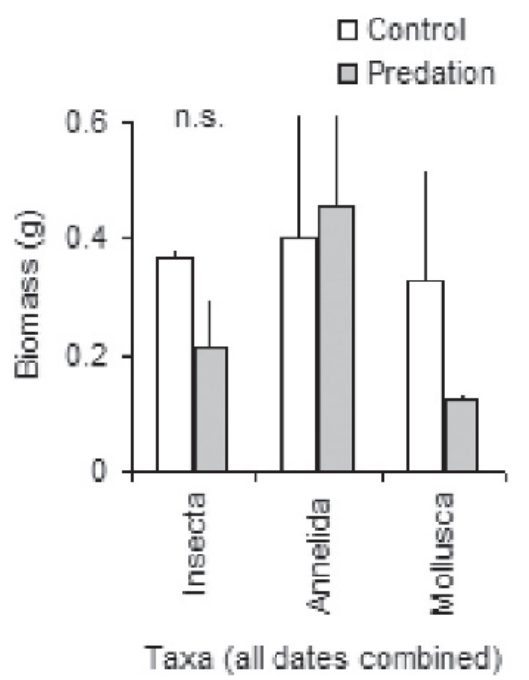

Fig. 3. Total biomass of insects, annelids, and molluscs in the predator addition enclosures and enclosure controls for all manipulations combined in Vandorf Pond (average \pm 1 SE per $0.03 \mathrm{~m}^{2}$ box sampler, $n=2$ ). No treatment effects were statistically significant (n.s., Bonferroni corrected $P>0.033$ ).

total insects, $27100 \pm 800 \mathrm{~m}^{-2}$ annelids, and $9900 \pm$ $3100 \mathrm{~m}^{-2}$ molluscs). The biomass of insects, annelids and molluscs inside the enclosures did not differ from the biomass in the pondwater outside of the enclosures (n.s.).

\section{Dipterans and zooplankton}

The abundance of dipterans was not affected by the enclosures (i.e., abundance inside the enclosure controls did not differ from the surrounding pondwater, n.s.). The abundance of cyclopoids was higher inside the enclosure controls $\left(121100 \pm 25800 \mathrm{~m}^{-2}\right)$ than in the surrounding pond water $\left(67300 \pm 7800 \mathrm{~m}^{-2}, P<0.025\right)$, whereas abundances of ostracods and cladocerans were lower inside $\left(15700 \pm 500 \mathrm{~m}^{-2}\right.$ ostracods and $500 \pm 300 \mathrm{~m}^{-2}$ cladocerans) than outside the enclosures $\left(121100 \pm 25800 \mathrm{~m}^{-2}\right.$ ostracods and $38900 \pm 1000 \mathrm{~m}^{-2}$ cladocerans, $\left.P<0.025\right)$. Large planktonic crustaceans $(\mathrm{p}>1 \mathrm{~mm})$ were less abundant inside $\left(1300 \pm 50 \mathrm{~m}^{-2}\right)$ than outside the enclosures $\left(4300 \pm 1700 \mathrm{~m}^{-2}, P<0.033\right)$. Large benthic crustaceans $(b>1 \mathrm{~mm})$ and small crustaceans $(p+b<1 \mathrm{~mm})$ were not affected by the enclosures (n.s.).

\section{Lower trophic levels}

With the exception of crustaceans $(P<0.014)$, abundances of meiofauna and benthic microfauna taxa were not affected by the enclosures (n.s.). The enclosure controls had higher concentrations of phytoplankton $\left(15.4 \pm 0.8 \mu \mathrm{g}\right.$ Chl $\left.a . \mathrm{L}^{-1}\right)$, periphyton $(103.8 \pm 5.5 \mu \mathrm{g}$ Chl a. $\left.\mathrm{cm}^{-2}\right)$, and ciliates $\left(6700 \pm 11700 \mathrm{~mL}^{-1}\right)$ compared with the surrounding pond water $\left(4.3 \pm 0.5 \mu \mathrm{g} . \mathrm{L}^{-1}\right.$ phytoplankton $\mathrm{Chl} a, 17.8 \pm 18.6 \mu \mathrm{g} . \mathrm{cm}^{-2}$ periphyton Chl $a$, and $270 \pm 20 \mathrm{~mL}^{-1}$ ciliates, $\left.P<0.025\right)$. The enclosures did not affect the concentration of bacteria (n.s.). Turbidity was 18 FTU units lower inside the enclosures compared with the surrounding pond water $(P<0.033)$. The enclosures did not affect concentrations of dissolved oxygen or phosphorus (n.s.).

\section{Discussion}

High productivity and strong seasonal variation in physicochemical variables, resources, and predator and prey assemblages in Vandorf Pond (Magnusson and Williams, 2006; this study) did not prevent the dytiscid larvae and odonate nymphs to significantly affect several trophic levels in the pond food web, either by direct predation or indirectly through trophic cascades. Many treatment effects appeared to be prey-specific and linked to predator type or time. 

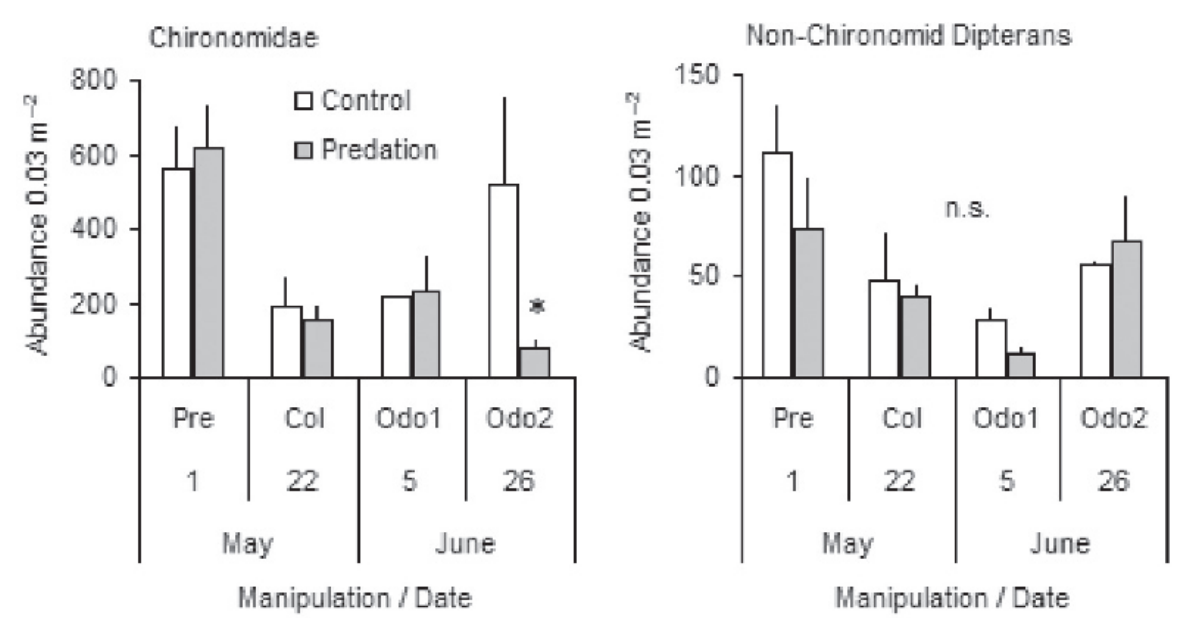

Fig. 4. Total abundance of chironomids and non-chironomid dipterans in the predator addition enclosures and enclosure controls during each manipulation in Vandorf Pond (average \pm 1 SE per $0.03 \mathrm{~m}^{2}$ box sampler, $n=2$ ). Statistically significant differences between the treatment and enclosure control in each manipulation is denoted with an asterisk (Bonferroni corrected $P<0.05$ ) and nonsignificant effects are denoted n.s.
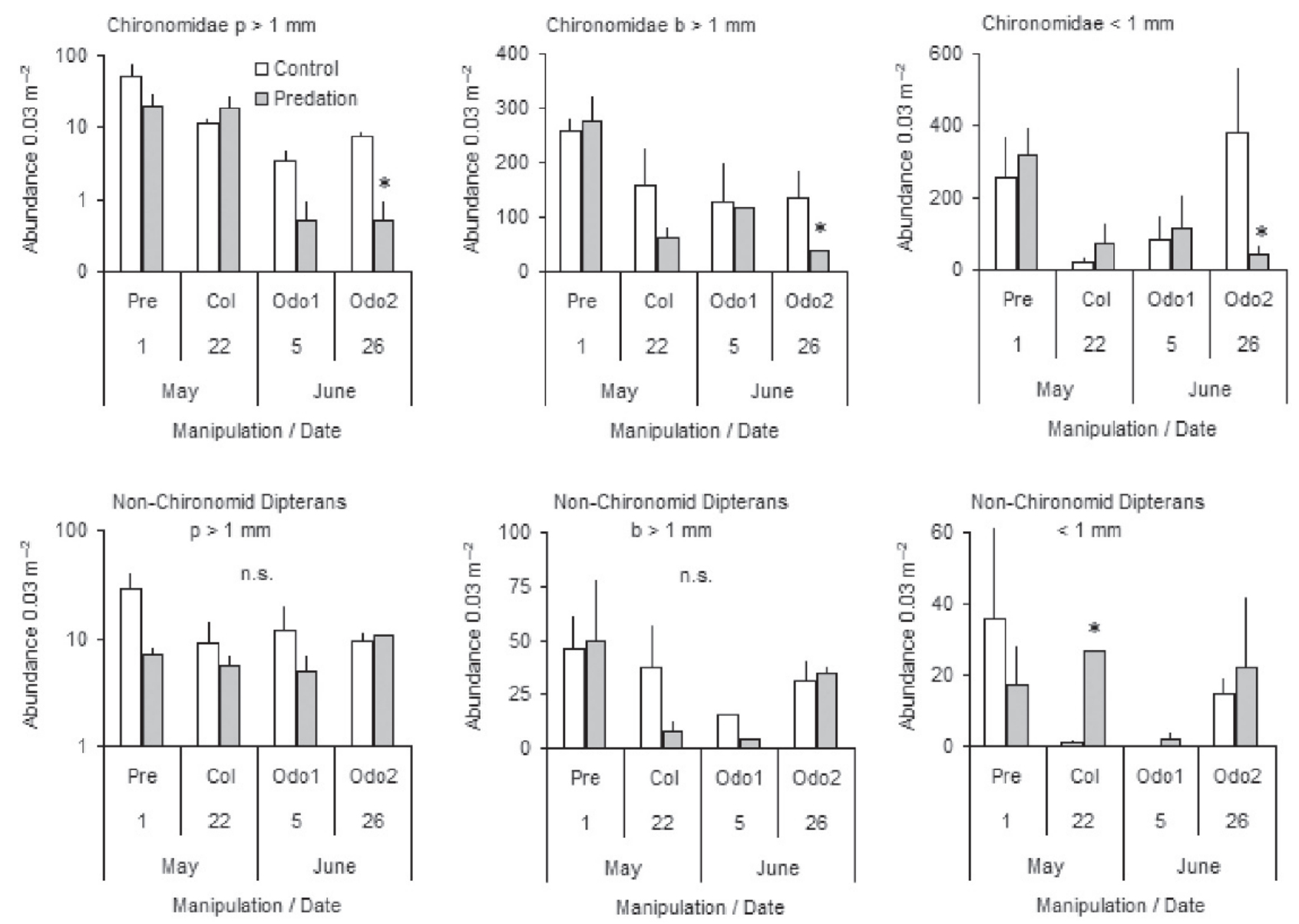

Fig. 5. Total abundance of chironomids and non-chironomid dipterans based on size $(>1 \mathrm{~mm}$, or $<1 \mathrm{~mm})$ and habitat (lower panels; $\mathrm{p}=$ planktonic; $\mathrm{b}=$ benthic) in the predator addition enclosures and enclosure controls during each manipulation in Vandorf Pond (average \pm 1 SE per $0.03 \mathrm{~m}^{2}$ box sampler, $n=2$ ). Statistically significant differences between the treatment and enclosure control in each manipulation are denoted with an asterisk (Bonferroni corrected $P<0.017$ ) and non-significant effects are denoted n.s.

Dytiscid larvae are piercers (i.e., feeding on body fluids) and were expected to affect mainly large prey and ignore smaller prey, such as zooplankton $(c f$. ., Tate and
Hershey, 2003). The addition of dytiscid predators to the predator enclosures was followed by lower abundance of dipterans but also of lower abundance of zooplankton 


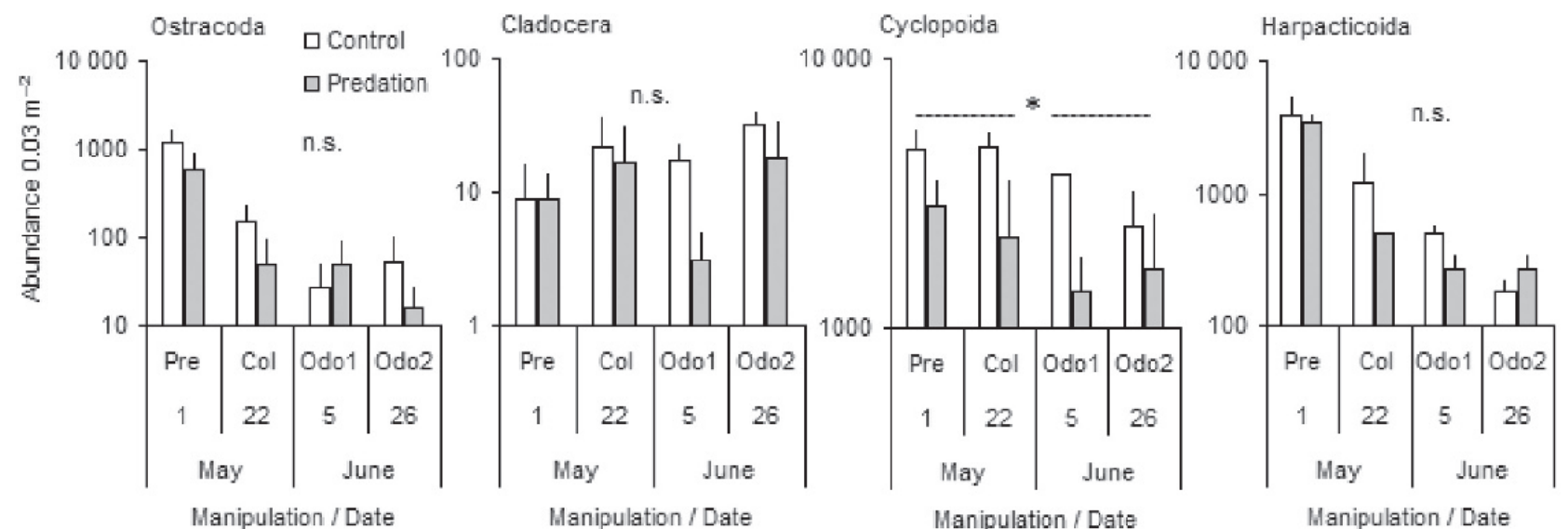

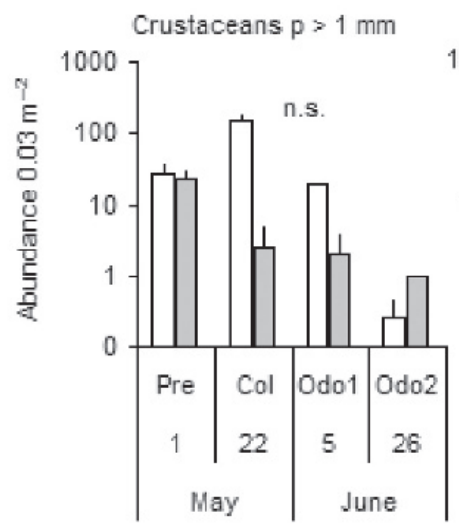

Manipulation / Date

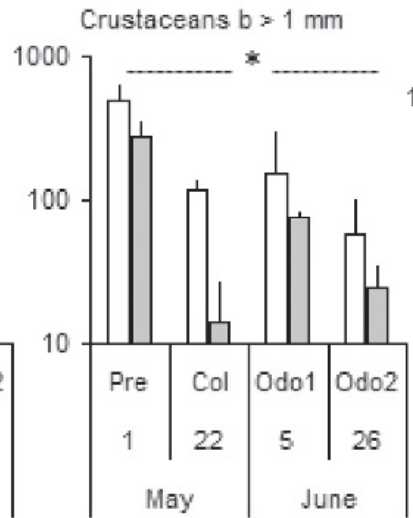

Manipulation / Date

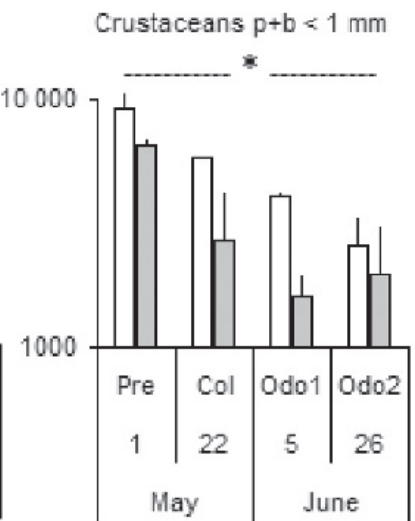

Manipulation / Date

Fig. 6. Total abundance of major zooplankton taxa (top panels) and based on size ( $>1 \mathrm{~mm}$, or $<1 \mathrm{~mm}$ ) and habitat (lower panels; $\mathrm{p}=$ planktonic, $\mathrm{b}=$ benthic) in the predator addition enclosures and enclosure controls during each manipulation in Vandorf Pond (average $\pm 1 \mathrm{SE}$ per $0.03 \mathrm{~m}^{2}$ box sampler, $n=2$ ). Statistically significant differences between the treatment and enclosure control in each manipulation are denoted with an asterisk (Bonferroni corrected $P<0.025$ for the top panels and $P<0.033$ for the lower panels) and non-significant effects are denoted n.s.

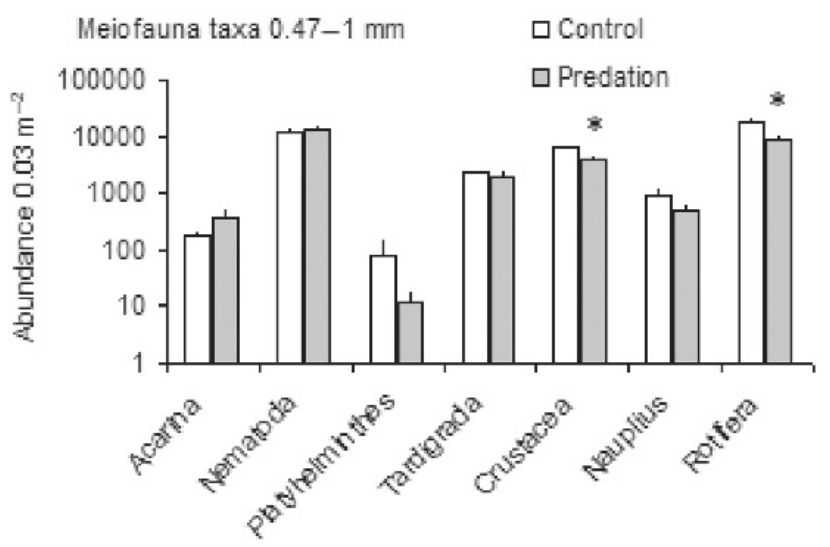

Taxa (all dates combined)

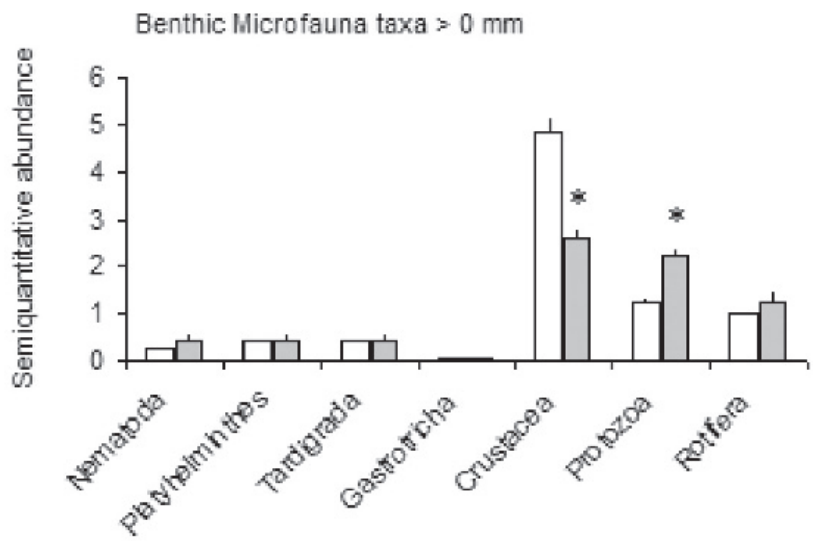

Taxa (all dates combined)

Fig. 7. Total abundance of (a) meiofaunal taxa, and (a) benthic microfaunal taxa (scale $0-8$, with $0=$ not present in any samples, and $8=$ present in all samples in high abundances), in the predator addition enclosures and enclosure controls (average $\pm 1 \mathrm{SE}$ per $0.03 \mathrm{~m}^{2}$ box sampler, $n=2$ ), in all dates/manipulations combined in Vandorf Pond. Statistically significant differences between the treatment and enclosure control are denoted with an asterisk (Bonferroni corrected $P<0.014$ ). 

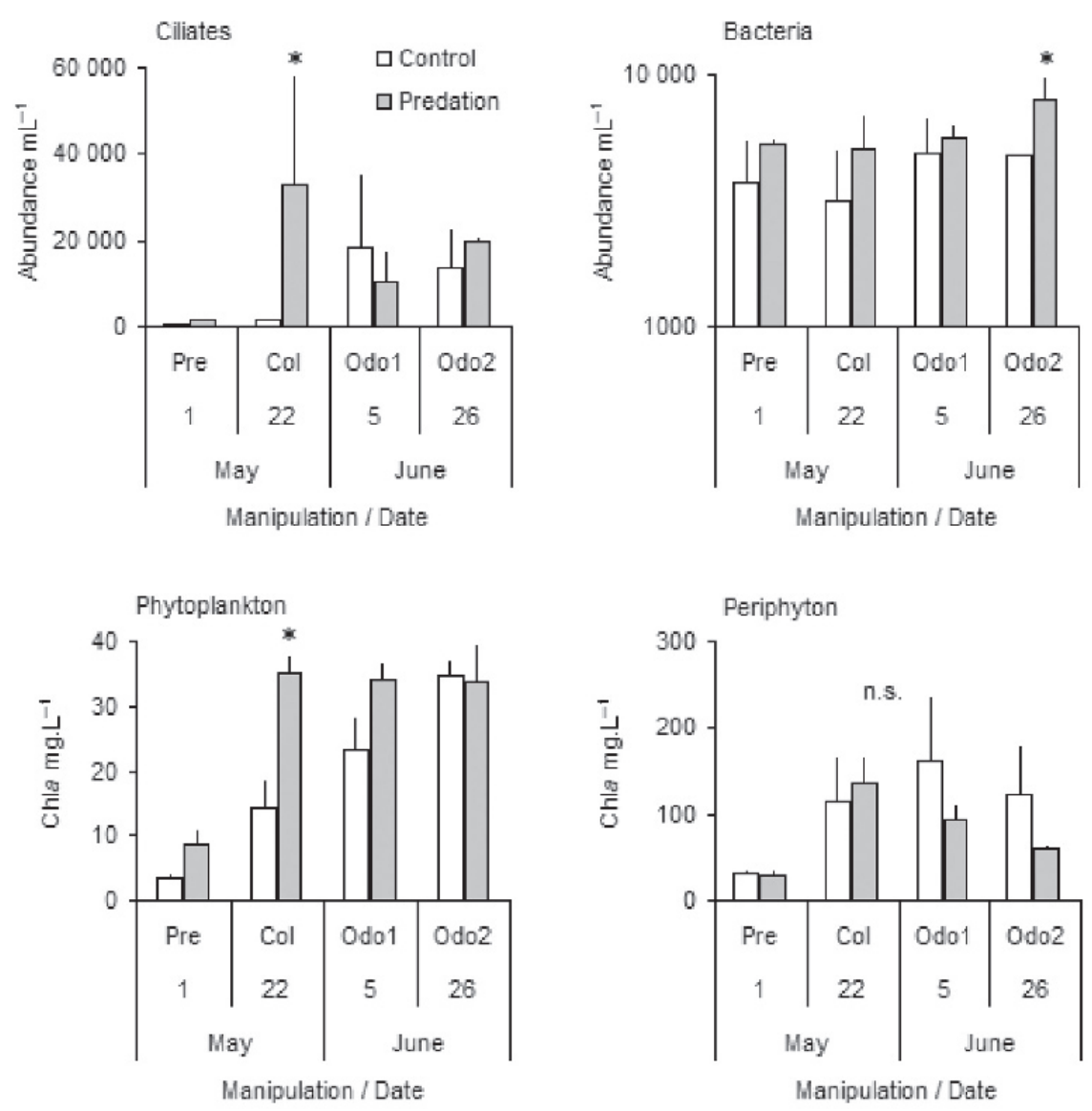

Fig. 8. Concentrations of ciliates, periphyton $(\mathrm{Chl} a)$, bacteria (log-scale), phytoplankton $(\mathrm{Chl} a)$, and periphyton $(\mathrm{Chl} a)$ in the predator addition enclosures and enclosure controls during each manipulation in Vandorf Pond (average $\pm 1 \mathrm{SE}, n=2$ ). Statistically significant differences between the treatment and enclosure control in each manipulation are denoted with an asterisk (Bonferroni corrected $P<0.025)$ and non-significant effects are denoted n.s.
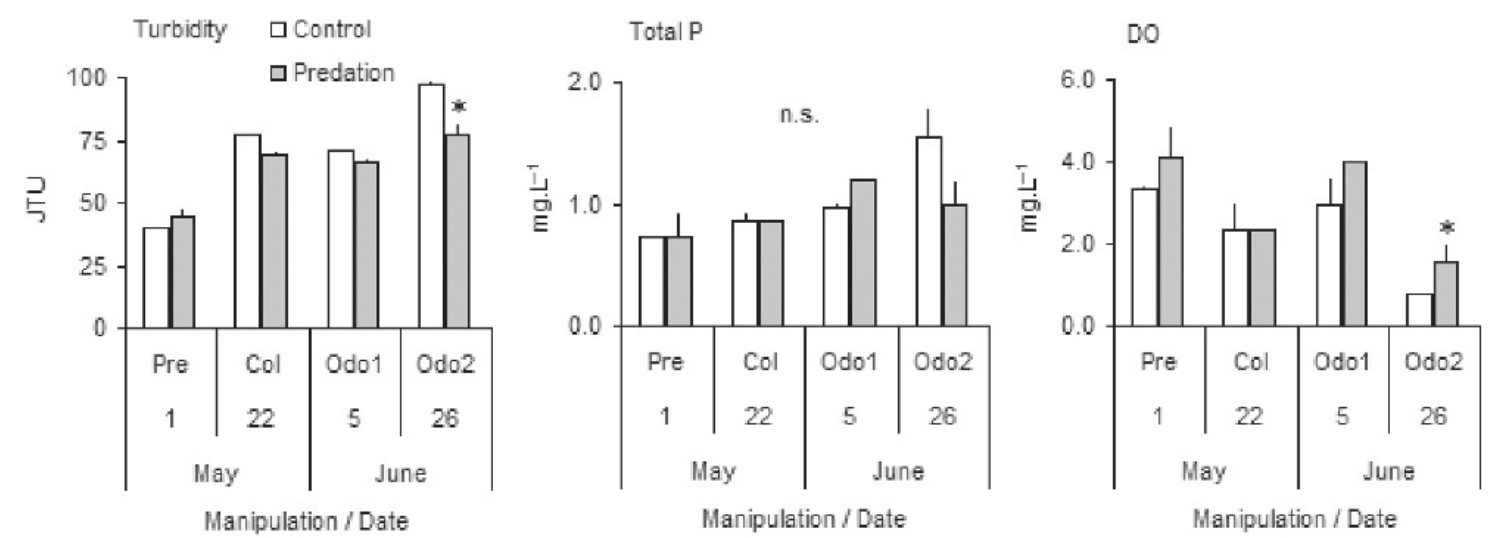

Fig. 9. Concentrations of selected physicochemical variables (turbidity, total phosphorus, and dissolved oxygen) in the predator addition enclosures and enclosure controls during each manipulation in Vandorf Pond (average \pm 1 SE, $n=2$ ). Statistically significant differences between the treatment and enclosure control in each manipulation are denoted with an asterisk (Bonferroni corrected $P<0.033)$ and non-significant effects are denoted n.s.

(compared with the enclosure control). Considering that dytiscid larvae are piercers, it is perhaps curious that they affected zooplankton to such a high degree. This finding contrasts with those by Koegel (1987) and Tate and Hershey (2003) who found that dytiscids prefers large-bodied prey before zooplankton, but agrees with other studies in which visual dytiscid larvae (such as Acilius) has been found to feed extensively on dipteran larvae (Nilsson, 1986) and zooplankton (Arts et al., 1981; Nilsson, 1986; Arnott et al., 2006). The dytiscids 
in Vandorf Pond enclosures preferred large dipterans and crustaceans (mainly ostracods and copepods) to cladocerans, but also reduced the abundance of small crustaceans.

Odonate nymphs are engulfers that choose larger prey as they grow ( $c f$., Corbet, 1999). Smaller odonates (i.e., early odonate addition) were expected to prefer smaller prey (i.e., zooplankton and small dipterans), whereas larger odonates (i.e., late odonate addition) were expected to prefer larger prey (i.e., large dipterans). The addition of early odonates (primarily $S$. internum) was followed by lower abundances of small crustaceans (e.g., cladocerans and copepods) and large non-chironomid dipterans (compared with the enclosure control). Cladocerans (which were ignored by the dytiscid larvae) appeared to be actively sought out by the early odonates, despite their relatively low abundance compared with other zooplankton and dipterans. During the three following weeks of odonate additions (i.e., late odonates), the added predators were of larger size and also included $S$. costiferum. These larger odonates appeared to prefer large chironomids and ignore smaller prey such as cladocerans and copepods (despite their abundance being many times higher than that of the chironomids) and non-chironomid dipterans. The shift from smaller to larger prey as the odonates grew was also observed in gut content analyses by Febria et al. (2005).

Dietary data from laboratory feeding experiments and gut content analysis of the top predators in Vandorf Pond by Febria et al. (2005) provided corroborative evidence for our interpretations of the predator effects because most of the affected prey in the predator addition enclosures agreed with the findings from the laboratory feeding experiments that Sympetrum nymphs and Acilius larvae captured and fed on all prey presented to them (e.g., chironomids, ostracods, cladocerans, and culicid larvae). On the other hand, some prey items found in the gut contents of Sympetrum were not significantly affected by the predator manipulations in the field (e.g., oligochaetes, nematodes, mites, leeches, dytiscid larvae, and other odonates, this study). In addition, it appeared that the added predators had a negative influence on the recruitment of molluscs (molluscs increased in abundance from May to June in the enclosure controls but not in the predator addition enclosures). It should be noted that all predators were added consecutively to the same enclosures in order to mimic the natural predator composition and therefore, effects from the odonate additions may have been influenced by the coleopteran additions and the late odonate additions also from the early odonate additions. Nevertheless, the results suggest that dytiscid larvae and odonate nymphs may occasionally feed on larger prey in Vandorf Pond, but that the bulk of their prey comprises zooplankton and chironomid larvae.

The effects from the predator additions in Vandorf Pond appeared to propagate down through the food web (see example of possible pathway in Fig. 10) because the decrease in intermediate-level feeders (e.g., zooplankton and chironomids) was accompanied by increasing abundances/concentrations in lower trophic levels (e.g., ciliates,

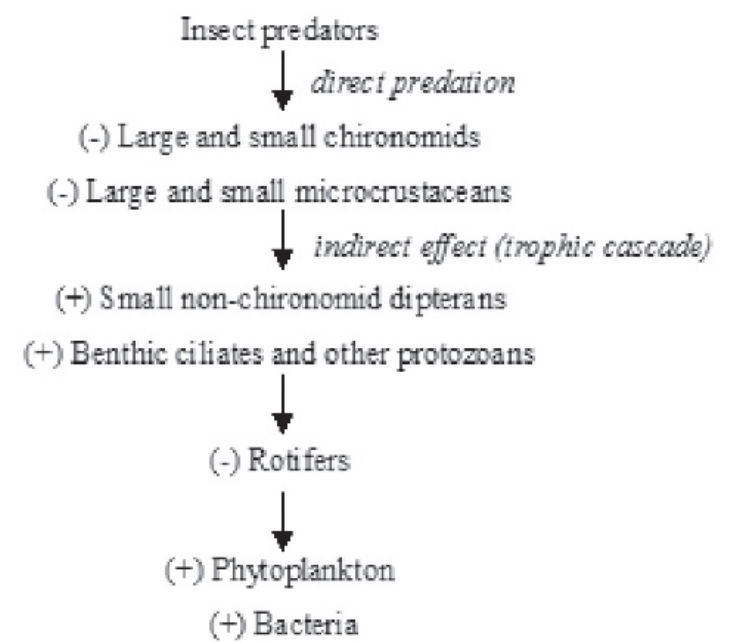

Fig. 10. Possible pathway of the effects from the predator addition in Vandorf Pond enclosures.

protozoans, bacteria, and phytoplankton) and by decreasing abundance of rotifers. Insect predators have been shown to affect rotifers, periphyton, and bacteria also in other studies (Hall et al., 1970; Thorp and Cothran, 1984; Batzer and Resh, 1991; Blaustein et al., 1995; Arner et al., 1998, Stav et al., 2000, Kneitel and Miller, 2002). Although small dragonfly nymphs and beetles may feed directly on rotifers and nauplii (Hampton and Gilbert, 2001; Kehl and Dettner, 2003), the response in rotifers in Vandorf Pond likely resulted from trophic cascades since the added predators were too large to efficiently feed directly on such small organisms. Copepods are known to be important intermediate-level organisms by feeding on bacterio-, and phytoplankton (review in Williamson and Reid, 2001). We hypothesize that the added predators in the Vandorf Pond enclosures removed sufficiently large numbers of chironomids and zooplankton to release predation pressure upon lower trophic level taxa (ciliates, protozoans, bacteria and phytoplankton), which consequently increased in abundance.

Some responses did not correspond in time, likely because other taxa and pathways were involved but concealed by omnivory, compensatory mechanisms and/or time-delays in the propagation through the food web. Omnivory is, for example, particularly extensive in lower trophic levels (e.g., Ortega-Mayagoita et al., 2002). Our results do suggest, however, that predator-prey interactions in this intermittent pond were strong and that the insect top-predators did regulate lower trophic levels in the food web.

Abundances of several taxa were affected by the enclosures in this study. Compared with the surrounding pondwater, the enclosure controls contained higher abundance/concentration of cyclopoids, phytoplankton and ciliates and slightly higher turbidity, but lower abundance of molluscs, ostracods, cladocerans, and large planktonic crustaceans. Thus, prevented movement of water and organisms and excluded access to shallow marginal habitats of the pond significantly affected 
the biota inside the enclosures. In addition, although the enclosures were as large as logistically possible, the enclosures may have increased the frequency of predator-prey encounter rates by excluding predator refuge for the more mobile prey and by allowing better sighting of prey by predators along the enclosure edges. Since all treatment effects in this report were contrasted to enclosed controls, and not the surrounding pondwater, the obtained results should be equally, if not more, realistic as those obtained from studies in which artificial experimental units, of any kind, are used.

\section{Conclusion}

Despite high productivity, rapid community development, and dense vegetation, which likely buffered against strong top-down control in the Vandorf Pond, taxa at several trophic levels were affected when the density of insect predators were manipulated in field enclosures. These results suggest that insect top predators may not only regulate lower trophic levels in systems that are permanent and stable, but also play an important role in systems with rapid community development and strong abiotic constraints.

Acknowledgements. We gratefully acknowledge funding for this project from the Natural Sciences and Engineering Research Council of Canada to D.D.W. We thank D. Boix, C. Febria, and several undergraduate students for help in the field and the lab and an anonymous referee whose suggestions improved this paper. We are also very grateful to Dr. and Mrs. P. van Nostrand for permission to work on their property.

\section{References}

Aditya G. and Saha G.K., 2006. Predation of the beetle Rhantus sikkimensis (Coleoptera: Dytiscidae) on the larvae of Chironomus meigen (Diptera: Chironomidae) of the Darjeeling Himalayas of India. Limnologica, 36, 251-257.

Andrushchyshyn O.P., Magnusson A.K. and Williams D.D., 2003. Ciliate populations in temporary freshwater ponds: seasonal dynamics and influential factors. Freshwat. Biol., 48, 548-564.

APHA (American Public Health Association), AWWA (American Water Works Association) and WPCF (Water Pollution Control Federation), 1995. 10200H Chlorophyll. In: American Public Health Association Standard Methods for the Examination of Water and Wastewater, 10.17-10.24.

Arner M., Koivisto S., Norberg J. and Kautsky N., 1998. Trophic interactions in rockpool food webs: regulation of zooplankton and phytoplankton by Notonecta and Daphnia. Freshwat. Biol., 39, 79-90.

Arnott S.E., Jackson A.B. and Alarie Y., 2006. Distribution and potential effects of water beetles in lakes recovering from acidification. J. N. Am. Benthol. Soc., 25, 811-824.

Arts M.T., Maly E.J. and Pasitschniak M., 1981. The influence of Acilius (Dytiscidae) predation on Daphnia in a small pond. Limnol. Oceanogr., 26, 1172-1175.
Batzer D.P. and Resh V.H., 1991. Trophic interactions among a beetle predator, a chironomid grazer, and periphyton in a seasonal wetland. Oikos, 60, 251-257.

Batzer D.P. and Wissinger S.A., 1996. Ecology of insect communities in nontidal wetlands. Annu. Rev. Entomol., 41, 75-100.

Bazzanti M., Della Bella V. and Seminara M., 2003. Factors affecting macroinvertebrate communities in astatic ponds in central Italy. J. Freshwat. Ecol., 18, 537-548.

Berninger U.G., Finlay B.J. and Kuuppoleinikki P., 1991. Protozoan control of bacterial abundances in fresh-water. Limn. Oceanogr., 36, 139-147.

Biggs J., Williams P.M., Whitfield M., Nicolet P. and Weatherby A., 2005. 15 years of pond assessment in Britain: results and lessons learned from the work of pond conservation. Aquat. Conserv. Mar. Freshwat. Ecosyst., 15, 693-714.

Blaustein L., 1998. Influence of the predatory backswimmer, Notonecta maculata, on invertebrate community structure. Ecol. Entomol., 23, 246-252.

Blaustein L., Kotler B.P. and Ward D., 1995. Direct and indirect effects of a predatory backswimmer (Notonecta maculata) on community structure of desert temporary pools. Ecol. Entomol., 20, 311-318.

Burks R.L., Jeppesen E. and Lodge D.M., 2001. Littoral zone structures as Daphnia refugia against fish predators. Limnol. Oceanogr., 46, 230-237.

Carchini G., Della Bella V., Solimini A.G. and Bazzanti M., 2007. Relationships between the presence of odonate species and environmental characteristics in lowland ponds of central Italy. Ann. Limnol. - Int. J. Lim., 43, 81-87.

Cooper S.D., 1983. Selective predation on cladocerans by common pond insects. Can. J. Zool., 61, 879-886.

Corbet P.S., 1999. Dragonflies - Behavior and Ecology of Odonata, Comstock Publishing Associates, Cornell University Press, New York.

De Szalay F.A. and Resh V.H., 2000. Factors influencing macroinvertebrate colonization of seasonal wetlands: responses to emergent plant cover. Freshwat. Biol., 45, 295-308.

Deding J., 1988. Gut content analysis of diving beetles (Coleoptera: Dytiscidae). Natura Jutlandica, 22, 177-184.

Febria C.M., Magnusson A.K. and Williams D.D., 2005. Seasonal abundance and prey selection of the nymphs of three sympatric species of Sympetrum (Odonata: Libellulidae) in an intermittent pond. Can. Entomol., 137, 723-727.

Hall D.J., Cooper W.E. and Werner E.E., 1970. Experimental approach to production dynamics and structure of freshwater animal communities. Limnol. Oceanogr., 15, 839-928.

Hampton S.E. and Gilbert J.J., 2001. Observations of insect predation on rotifers. Hydrobiologia, 446, 115-121.

Hauser A., Attrill M.J. and Cotton P.A., 2006. Effects of habitat complexity on the diversity and abundance of macrofauna colonizing artificial kelp holdfasts. Mar. Ecol. Prog. Ser., $325,93-100$.

Hoekman D., 2007. Top-down and bottom-up regulation in a detritus-based aquatic food web: a repeated field experiment using the Pitcher plant (Sarracenia purpurea) inquiline community. Am. Midl. Nat., 157, 52-62.

Jeffries M., 1988. Individual vulnerability to predation the effect of alternative prey types. Freshwat. Biol., 19, 49-56. 
Jeffries M., 1996. Effects of Notonecta glauca predation on Cyphon larvae (Coleoptera: Scirtidae) populations in small, seasonal ponds. Arch. Hydrobiol., 136, 413-420.

Johansson A. and Nilsson A.N., 1992. Dytiscus latissimus and D. circumcinctus (Coleoptera, Dytiscidae) larvae as predators on 3 case-making caddis larvae. Hydrobiologia, 248, 201-213.

Johansson F. and Suhling F., 2004. Behaviour and growth of dragonfly larvae along a permanent to temporary water habitat gradient. Ecol. Entomol., 29, 196-202.

Johnson D.M., Pierce C.L., Martin T.H., Watson C.N., Bohanan R.E. and Crowley P.H., 1987. Prey depletion by odonate larvae-combining evidence from multiple field experiments. Ecology, 68, 1459-1465.

Kehl S. and Dettner K., 2003. Predation by pioneer water beetles (Coleoptera, Dytiscidae) from sandpit ponds, based on crop content analysis and laboratory experiments. Arch. Hydrobiol., 158, 109-126.

Kneitel J.M. and Miller T.E., 2002. Resource and top-predator regulation in the pitcher plant (Sarracenia purpurea) inquiline community. Ecology, 83, 680-688.

Koegel F., 1987. On the biology and ecology of Rhantus consputus strm. Coleoptera Dytiscidae. Entomol. Arb. Mus. G. Frey Tutzing Bei Muenchen, 35-36, 5-20.

Koperski P., 1998. What do the predatory, littoral insects eat? Wiad. Ekol., 44, 95-130.

Magnusson A.K. and Williams D.D., 2006. The roles of natural temporal and spatial variation versus biotic influences in shaping the physicochemical environment of intermittent ponds: a case study. Arch. Hydrobiol., 165, 537-556.

Nakano S., Ishii N., Manage P.M. and Kawabata Z., 1998. Trophic roles of heterotrophic nanoflagellates and ciliates among planktonic organisms in a hypereutrophic pond. Aquat. Microb. Ecol., 16, 153-161.

Nilsson A.N., 1986. Community structure in the Dytiscidae (Coleoptera) of a northern swedish seasonal pond. Ann. Zool. Fenn., 23, 39-47.

Nilsson A.N. and Söderström O., 1988. Larval consumption rates, interspecific predation, and local guild composition of egg-overwintering Agabus (Coleoptera, Dytiscidae) species in vernal ponds. Oecologia, 76, 131-137.

Ortega-Mayagoita E., Rojo C. and Rodrigo M.A., 2002. Factors masking the trophic cascade in shallow eutrophic wetlands: evidence from a microcosm study. Arch. Hydrobiol., 155, 43-63.

Peckarsky B.L., 1982. Aquatic insect predator-prey relations. Bioscience, 32, 261-266.

Pritchard G., 1964. The prey of dragonfly larvae (Odonata; Anisoptera) in ponds in northern Alberta. Can. J. Zool., 42, 785-800.

Pritchard G., 1965. Prey capture by dragonfly larvae (OdonataAnisoptera). Can. J. Zool., 43, 271-289.

Rubbo M.J., Mirza R.S., Belden L.K., Falkenbach J.J., Storrs S.I. and Kiesecker J.M., 2006. Evaluating a predator-prey interaction in the field: the interaction between beetle larvae (predator) and tadpoles (prey). J. Zool., 269, 1-5.

Schmid-Araya J.M. and Schmid P.E., 2000. Trophic relationships: integrating meiofauna into a realistic benthic food web. Freshwat. Biol., 44, 149-163.

Schneider D.W., 1997. Predation and food web structure along a habitat duration gradient. Oecologia, 110, 567-575.

Schneider D.W., 1999. Snowmelt ponds in Wisconsin - Influence of hydroperiod on invertebrate community structure. In: Batzer D.P., Rader R.B. and Wissinger S.A. (eds.), Invertebrates in Freshwater Wetlands of North America Ecology and Management, John Wiley and Sons, Inc., New York.

Schneider D.W. and Frost T.M., 1996. Habitat duration and community structure in temporary ponds. J. N. Am. Benthol. Soc., 15, 64-86.

Sih A., Crowley P., McPeek M., Petranka J. and Strohmeier K., 1985. Predation, competition, and prey communities $-\mathrm{A}$ review of field experiments. Annu. Rev. Ecol. Syst., 16, 269-311.

Smith R.F. and Pritchard A.E., 1968. Odonata. Aquatic Insects of California. In: Usinger R.L. (ed.), University of California Press, 106-109.

Stav G., Blaustein L. and Margalit Y., 2000. Influence of nymphal Anax imperator (Odonata: Aeshnidae) on oviposition by the mosquito Culiseta longiareolata (Diptera: Culicidae) and community structure in temporary pools. J. Vect. Ecol., 25, 190-202.

Taniguchi H. and Tokeshi M., 2004. Effects of habitat complexity on benthic assemblages in a variable environment. Freshwat. Biol., 49, 1164-1178.

Tate A. and Hershey A., 2003. Selective feeding by larval dytiscids (Coleoptera: Dytiscidae) and effects of fish predation on upper littoral zone macroinvertebrate communities of arctic lakes. Hydrobiologia, 497, 13-23.

Thorp J.H. and Cothran M.L., 1984. Regulation of fresh-water community structure at multiple intensities of dragonfly predation. Ecology, 65, 1546-1555.

Wellborn G.A., Skelly D.K. and Werner E.E., 1996. Mechanisms creating community structure across a freshwater habitat gradient. Annu. Rev. Ecol. Syst., 27, 337-363.

Wiggins G.B., Mackay R.J. and Smith I.M., 1980. Evolutionary and ecological strategies of animals in annual temporary pools. Arch. Hydrob. Suppl., 58, 97-226.

Williams D.D., 2006. The Biology of Temporary Waters, Oxford University Press.

Williamson C.E. and Reid J.W., 2001. Copepoda. In: Thorp J.H. and Covich A.P. (eds.), Ecology and Classification of North American Freshwater Invertebrates, 2nd edition, Academic Press, New York, 915-954.

Wojdak J.M., 2005. Relative strength of top-down, bottom-up, and consumer species richness effects on pond ecosystems. Ecol. Monogr., 75, 489-504. 